\title{
A Study of High Sensitivity C-Reactive Protein (hsCRP) in Relation to HbA1C in Type2 Diabetes Mellitus in Tertiary Care Hospital, Mysore
}

\author{
Ramesh S S ${ }^{1}$, Basavaraju $\mathbf{M ~ M}^{2}$, Shashikanth Y $\mathbf{S}^{3}$ \\ ${ }^{1}$ Associate Professor, Department of Medicine, Mysore Medical College and Research Institute ${ }^{2}$ Associate Professor, \\ Department of Medicine, Mysore Medical College and Research Institute, ${ }^{3}$ Junior Resident, Department of medicine, \\ Mysore Medical College and Research Institute
}

Corresponding author: Dr. Basavaraju M M, Associate Professor, Department of medicine, Mysore Medical College and Research Institute

DOI: http://dx.doi.org/10.21276/ijcmsr.2019.4.1.15

How to cite this article: Ramesh S S, Basavaraju M M, Shashikanth Y S. A study of high sensitivity c-reactive protein (hsCRP) in relation to $\mathrm{HbA1C}$ in type2 diabetes mellitus in tertiary care hospital, Mysore. International Journal of Contemporary Medicine Surgery and Radiology. 2019;4(1):A62-A64.

\section{A B S T R A C T}

Introduction: Diabetes mellitus has become a leading cause of morbidity and mortality world over. hs-CRP is a marker of low-grade inflammation and it is raised in patients with type 2 DM. The present study was undertaken with objective of studying the relation of High Sensitivity CRP(hs-CRP) with HbA1c in type 2 Diabetes Mellitus.

Material and Methods: An observational cross section study was carried out in patients with Diabetes mellitus admitted in medicine ward and not suffering from any other inflammatory condition. The hs-CRP levels were measured by Nephalometeranalyser system and $\mathrm{HbA} 1 \mathrm{C}$ was performed by high performance liquid chromatography.

Results:Out of 77 subjects, 7 patients had low hs-CRP levels, 15 had intermediate and 55 had high hs-CRP levels. It was observed that patients with higher HbA1C levels had higher hs-CRP levels.

Conclusion: In this study, hs-CRP levels positively correlated with $\mathrm{HbA} 1 \mathrm{C}$ levels in type 2 diabetic patients.

Keywords: HbA1c,Type 2 Diabetes Mellitus, hsCRP

\section{INTRODUCTION}

Diabetes mellitus (DM) refers to a group of common metabolic disorders that share the phenotype of hyperglycemia. ${ }^{1}$ There has been an increasing interest in the involvement of low grade inflammation in the pathogenesis of type 2 diabetes ${ }^{2}$

The mechanisms by which chronic inflammation can evoke type 2 diabetes are not clear. However it is known that adipose tissue can synthesize and release the main pro inflammatory cytokines -tumor necrosis factor-alpha (TNF- $\alpha$ ), interlelukin-1 (IL-1) and interleukin-6 (IL-6) and that inflammatory markers are associated with body fat mass. Pro-inflammatory cytokines and acute phase reactants are involved in multiple metabolic pathways relevant to insulin resistance, including regulation, reactive oxygen species, lipoprotein lipase action and adipocyte function.

$\mathrm{C}$-reactive protein (CRP) is an acute-phase protein,which is an inflammatory marker produced and released by the liver under the stimulation of cytokines. It is a strong biomarker of inflammation in the progression of various diseases like coronary heart disease, cancer, diabetes, and others. It has emerged as the 'golden marker for inflammation. The hsCRP test is a highly sensitive quantification of CRP. The present study was undertaken with objective of studying the relation of High Sensitivity CRP(hs-CRP) with $\mathrm{HbA1c}$ in type 2 Diabetes Mellitus.

\section{MATERIAL AND METHODS}

This was an observational cross section study done in Krishna Rajendra Hospital, which is a tertiary care centre attached to Mysore Medical College and Research Institute, Mysuru. The study was carried out in the duration between July 2017 to December 2017. The study was done after approval from the institutional ethics committee. An informed written consent was obtained from the patients prior to inclusion in the study. This observational study carried out in 77 patients with type $2 \mathrm{DM}$ (according to ADA criteria ${ }^{3}$ ) admitted in medicine ward and not suffering from any active or chronic inflammatory disease.

HbA1C was performed by high performance liquid chromatography and High sensitivity CRP was analysed using a modification of Behring Latex Enhanced CRPSA on the Behring Nephlometer analyser system with a $2 \%$ inter assay coefficient of variation.

Cases were classified on their relative risk of future cardiovascular events as:

- Low risk: hs-CRP $<1.0 \mathrm{mg} / \mathrm{L}$

- Intermediate risk: hs-CRP 1.0-3.0 mg/L

- High risk: hs-CRP > $3.0 \mathrm{mg} / \mathrm{L}$ 


\section{STATISTICAL ANALYSIS}

Continuous data are expressed as means with standard deviations, and categorical data are expressed as numbers and percentages. ANOVA test was used for comparing categorical variables between High sensitivity CRP and HbA1C.

\section{RESULTS}

\section{Age Distribution}

In the present study, a sum total of 77 cases were included in which $12(16 \%)$ subjects were in the age group of 36- 45 years, $31(40 \%)$ subjects in the age group of 46-55 years and $34(44 \%)$ subjects in the age group of $\geq 56$ years ie. most of our cases are in this age group.

\section{Gender distribution}

In our study of 77 subjects, 44 (57\%) subjects were males and $33(43 \%)$ subjects were females (figure-2).

\section{hs-CRP relative risk}

In our study 7 (9\%) patients had low hs-CRP levels, 15 (20\%) had intermediate and 55 (71\%) had high hs-CRP levels (figure-2).

\section{Correlation between hs-CRP and mean age in years}

In our study the mean age of subject with hs-CRP of $<1$ is $51.14 \pm 7.5$ years, mean age of subjects with hs-CRP of $1-3$ is

\begin{tabular}{|l|c|c|}
\hline Age in years & Subjects, $\mathbf{N}=\mathbf{7 7}$ & Percentage \\
\hline $36-45$ & 12 & 16 \\
\hline $46-55$ & 31 & 40 \\
\hline$\geq 56$ & 34 & 44 \\
\hline \multicolumn{2}{|c|}{ Table-1: Table showing age distribution of subjects. } \\
\hline
\end{tabular}

\begin{tabular}{|l|c|}
\hline hs-CRP in $\mathbf{~ m g / d l ~}$ & Mean age in years \\
\hline$\leq 1$ & $51.14 \pm 7.5$ \\
\hline $1-3$ & $57.53 \pm 8.14$ \\
\hline$\geq 3$ & $53.56 \pm 7.64$ \\
\hline $\begin{array}{c}\text { Table-2: Table showing correlation between hs-CRP and mean } \\
\text { age in years }\end{array}$ \\
\hline
\end{tabular}

\begin{tabular}{|l|c|}
\hline hs-CRP in $\mathbf{~ g / d l}$ & Fasting blood sugar $\mathbf{~ m g / d l}$ \\
\hline$\leq 1$ & $130.85 \pm 49.17$ \\
\hline $1-3$ & $159.20 \pm 54.36$ \\
\hline$\geq 3$ & $177.58 \pm 55.86$ \\
\hline \multicolumn{2}{|c|}{ Table-3: Correlation between hs-CRP and fasting blood sugar } \\
\hline
\end{tabular}

\begin{tabular}{|l|c|}
\hline hs-CRP in $\mathbf{~ m g / d l ~}$ & Post prandial blood sugar $\mathbf{~ m g / d l}$ \\
\hline$\leq 1$ & $224.00 \pm 45.46$ \\
\hline $1-3$ & $255.46 \pm 104.59$ \\
\hline$\geq 3$ & $274.70 \pm 80.42$ \\
\hline \multicolumn{2}{|c|}{ Table-4: Correlation between hs-CRP and post prandial blood } \\
sugar
\end{tabular}

\begin{tabular}{|l|c|}
\hline hs-CRP in $\mathbf{~ m g / d l}$ & HbA1C \\
\hline$\leq 1$ & $7.52 \pm 1.03$ \\
\hline $1-3$ & $8.15 \pm 1.11$ \\
\hline$\geq 3$ & $8.90 \pm 1.24$ \\
\hline \multicolumn{2}{|c|}{ Table-5: Correlation between hs-CRP and HbA1c } \\
\hline
\end{tabular}

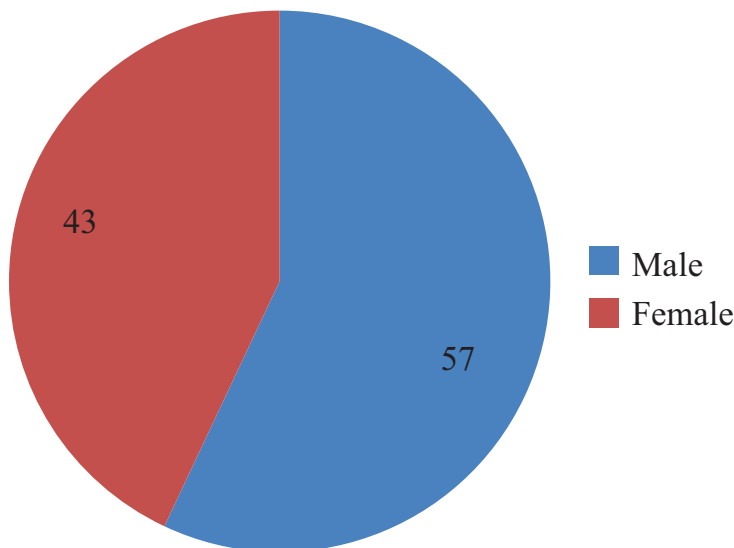

Figure-1: Figure showing gender distribution among subjects

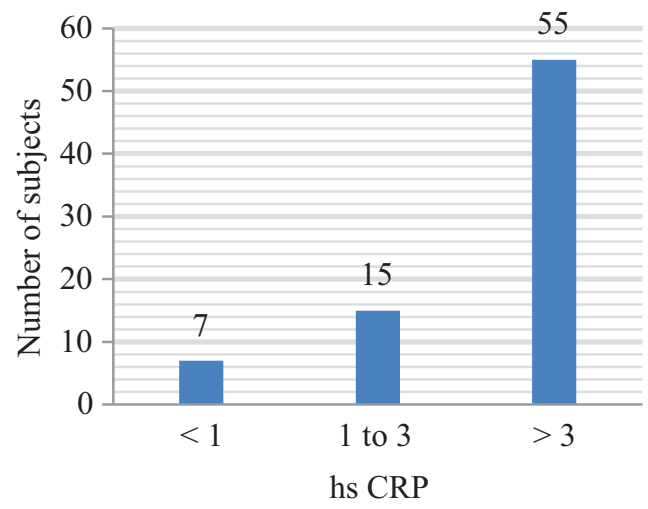

Figure-2: Figure showing distributions of subjects according to hs-CRP relative risk

$57.53 \pm 8.14$ years and mean age of subjects with hs-CRP of $\geq 3$ is $53.56+7.64$, p value of 0.127 (table-2).

Correlation between hs-CRP and fasting blood sugar In our study the mean of FBS with hs-CRP of $<1130.85+$ $49.17 \mathrm{mg} / \mathrm{dl}$, mean of FBS with hs-CRP of $1-3$ is $159.20+$ $54.36 \mathrm{mg} / \mathrm{dl}$ and mean of FBS with hs-CRP of > 3 is 177.58 $+55.86, \mathrm{p}$ value of 0.080 (table-3).

\section{Correlation between hs-CRP and post prandial blood sugar}

In our study the mean of PPBS with hs-CRP of $\leq 1$ is $224.00 \pm 45.46 \mathrm{mg} / \mathrm{dl}$, mean of PPBS with hs-CRP of $1-3$ is $255.46 \pm 104.59 \mathrm{mg} / \mathrm{dl}$ and mean of PPBS with hs-CRP of $\geq 3$ is $274.70 \pm 80.42$, p value of 0.248 .

\section{Correlation between hs-CRP and $\mathrm{HbA1c}$}

In our study the mean of $\mathrm{HbA} 1 \mathrm{C}$ with hs-CRP of $\leq 1$ is $7.52 \pm 1.03$, mean of $\mathrm{HbA} 1 \mathrm{C}$ with hs-CRP of $1-3$ is $8.15 \pm 1.11$ and mean of $\mathrm{HbA} 1 \mathrm{C}$ with hs-CRP of $\geq 3$ is $8.90 \pm 1.24, \mathrm{p}$ value of 0.004 .

\section{DISCUSSION}

It has been suggest that low grade inflammation may play a role in the development and complications of type 2 Diabetes mellitus.As concluded by various studies Pick up et $\mathrm{al}^{7}$ suggested an increasing interest in the involvement of low grade inflammation in the pathogenesis of type 2 diabetes. Laaksonan et $\mathrm{al}^{8}$, in their prospective study suggested that an elevated level of CRP is associated with an increased risk of 
developing type 2 diabetes.

Festa et $\mathrm{al}^{9}$ demonstrated that elevated levels of CRP are associated with obesity, insulin resistance and glucose intolerance, suggesting that inflammation is also involved in the etiology of type 2 diabetes.

In the present study, we found significant relation between hS-CRP and HbA1C levels with $\mathrm{p}$ value of 0.004 in patients of type 2 Diabetes mellitus .

Our findings are consistent with some of thestudies. In a national survey study, subjects with $\mathrm{HbA1C}$ levels $\geq 9 \%$ had a significantly higher rate of elevated CRP than those with HbA1C levels < 7\%. This suggests an association between poor glycemic control and systemic inflammation in people with established diabetes. ${ }^{10}$

Sangappa Virupaxappa Kashinakunti et al. ${ }^{11}$ in a study on serum high sensitivity - $\mathrm{C}$ reactive protein levels in Type 2 Diabetes Mellitus observed among statistically significant increase in all the biochemical parameters viz FBS, PPBS, $\mathrm{HbA} 1 \mathrm{c}$ and hs-CRP levels in cases as compared to controls. The $P$ value was 0.0001 for all the parameters, which is highly significant,but in our study hs-CRP was not significant with FBS and PPBS suggesting that these parameters are not a indicators for monitoring and prognostication as HbA1c. Study done by Yildiz Tutuncu et al ${ }^{12}$ on comparison of hs- CRP levels in new Diabetes groups observed a positive correlation between hs-CRP levels and age, BMI, waist, hip, SBP, DBP, pulse, FPG, HbA1c, TG, non-HDL cholesterol; and there was a negative correlation with HDL-cholesterol and eGFR,but in our study hs-CRP was not significant with age and it is suggesting that hs-CRP is not having positive correlation with age.

\section{CONCLUSION}

Raised levels ofhs-CRP in subjects with Type2 DM ,where $\mathrm{HbA1C}$ was above the target control level are prone for increased future relative risk of cardiovascular events and other complications. Hence Raised levels of hs-CRP indicates the role of ongoing inflammation in the management of diabetes. .

\section{Limitations}

This was a cross-sectional study, we could not establish a cause-effect relationship, further longitudinal studies are necessary to confirm the association between High Sensitivity C-reactive Protein and $\mathrm{HbA1C}$ also with respect to management and complications in type 2 diabetic patients.

\section{REFERENCES}

1. Jameson, Fauci, Kasper, Hauser, Longo, Loscalzo. Diabetes Mellitus. Chapter 396. In: Harrison's Principles of Internal Medicine. 20th edition. Vol 2.newyork:McGraw-Hill Education; 2018 pp 2850

2. Thorand B, Lowel H, Schneider A et al. $\mathrm{C}$-reactiveproteim as a predictor for incident diabetes mellitus among middle-aged men: Results from the MONICA Augsburg cohortstudy, 1984-1998. Arch Intern Med 2003; 163(1): 93-9.

3. American Diabetes Association. Standards of medical care in diabetes. Diabetes Care 2012;35(1):S11-63

4. Nakanishi S, Yamane K, Kamei $\mathrm{N}$ et al. Elevated
Creactive protein is a risk factor for thedevelopment of type 2 diabetes in Japanese Americans. Diabetes Care 2003; 26(3): 2754-7.

5. Chiriboga DE, Ma Y, Li W et al. Seasonal and gender variation of the high sensitivity $\mathrm{C}$ - reactive protein in healthy adults: A Longitudinal study. Clinical Chemistry 2009; 55(6): 313-21.

6. Jager A, Van Hinsberg VW, Kostense PJ et al. CRP and five year mortality in diabetic subjects: The Hoorn study. Arteioscler Throm Vase Biol 1999; 12(2): 3071-80.

7. Pickup JC. Inflammation and activated innate immunity in the pathogenesis of type 2 diabetes. Diabetes Care. 2004;27(3):813-23.

8. Laaksonen DE,Niskanen L, Nyyssonen K et al. Creactive protein and the development of the metabolic syndrome and diabetes in middle-aged men. Diabetologia 2004; 47(1): 1403-10.

9. Festa A, D’Agostino R Jr, Tracy RP,Haffner SM: Elevated levels of acute phase proteins and plasminogen activator inhibitor-1 predict the development of type 2 diabetes: the Insulin Resistance Atherosclerosis Study. Diabetes 2002;51(3):1131-1137.

10. King DE, Mainous AG 3rd, Buchanan TA, Pearson WS. C-reactive protein and glycemiccontrol in adults with diabetes. Diabetes Care. 2003;26(5):1535-9.

11. Sangappa Virupaxappa Kashinakunti, Manjula Rangappa Gurupadappa Shantappa Kallaganada. Serum High Sensitive - C Reactive Protein Levels in Type 2 Diabetes Mellitus -A Case Control Study. International Journal of Biochemistry Research \& Review 2016;11(4): 1-8.

12. Yildiz Tutuncu, Ilhan Satman Selda Celik, Nevin Dinccag, Kubilay Karsidag, Aysegul Telci, Sema Genc, Halim Issever. A Comparison of hs-CRP Levels in New Diabetes GroupsDiagnosed Based on FPG, 2-hPG, or HbA1c Criteria. Journal of Diabetes Research. 2016, Article ID 5827041, 1-9.

\section{Source of Support: Nil; Conflict of Interest: None}

Submitted: 01-02-2019; Accepted: 12-02-2019; Published online: 15-03-2019 